\title{
LABOR MIGRATION TODAY. TRENDS AND CONSEQUENCES
}

\author{
Marius Constantin PROFIROIU ${ }^{1}$ \\ Carmen Valentina RADULESCU ${ }^{2}$ \\ Sorin BURLACU ${ }^{3}$
}

DOI: $10.24818 / \mathrm{IMC} / 2020 / 05.17$

\begin{abstract}
The topic of migration and the nature of the economic effects of countries receiving immigrants are one of the topics of concern in the current debate. Nevertheless, neither the causes nor the consequences of migration seem to be well understood, nor is it clear how studies will proceed in this direction in the future. Discussions converge, however on agreeing that immigration has become a complex phenomenon, causing controversy in the research effort, especially in the host region of Europe. In Europe today, the Free Movement Agreement within the European Union is paving the way for labour migration across national borders. The impact of migration on the domestic labor market is the most common approach. The evolution of external migration in Romania is not well-known in this case. On economic grounds, Western countries now need foreign labor. Some Western countries are beginning to experience a small natural population decrease, and this natural decline is being compensated for by immigration, so that the population does not change dramatically. This article analyzes the demographic implications especially because the young population defines the community that has emigrated for economic reasons in recent years. Regarding the financial aspects and the quality of life of Romanians, significant economic consequences have been found. We can also conclude that the migration process is, first of all, influenced by economic evolution, which opens up new possibilities for future study.
\end{abstract}

KEYWORDS: domestic labor market, European Union, immigration, labor migration.

JEL CLASSIFICATION: E2, J08

\section{INTRODUCTION}

As a result of the economic and political transition, the structural shifts that have taken place since 1989 in the demographic trends and population structure of Romania are reflected in the demographic condition of the past decades (Bran et al., 2020). For the past 30 years, Romania's population has declined and there are also no visible signs of recovery. The population loss can be the result of three independent or cumulative variables (Burlacu et al., 2019):

-negative, greater than normal migration, external net migration;

-the increase in the rate of death which exceeds the rate of birth;

-a reduction in the birth rate below the rate of mortality.

\footnotetext{
1 Bucharest University of Economic Studies, Romania, e-mail: profiroiu@gmail.com

2 Bucharest University of Economic Studies, Romania, e-mail: carmen-valentina.radulescu@eam.ase.ro

3 Bucharest University of Economic Studies, Romania, e-mail: sburlacu@amp.ase.ro
} 


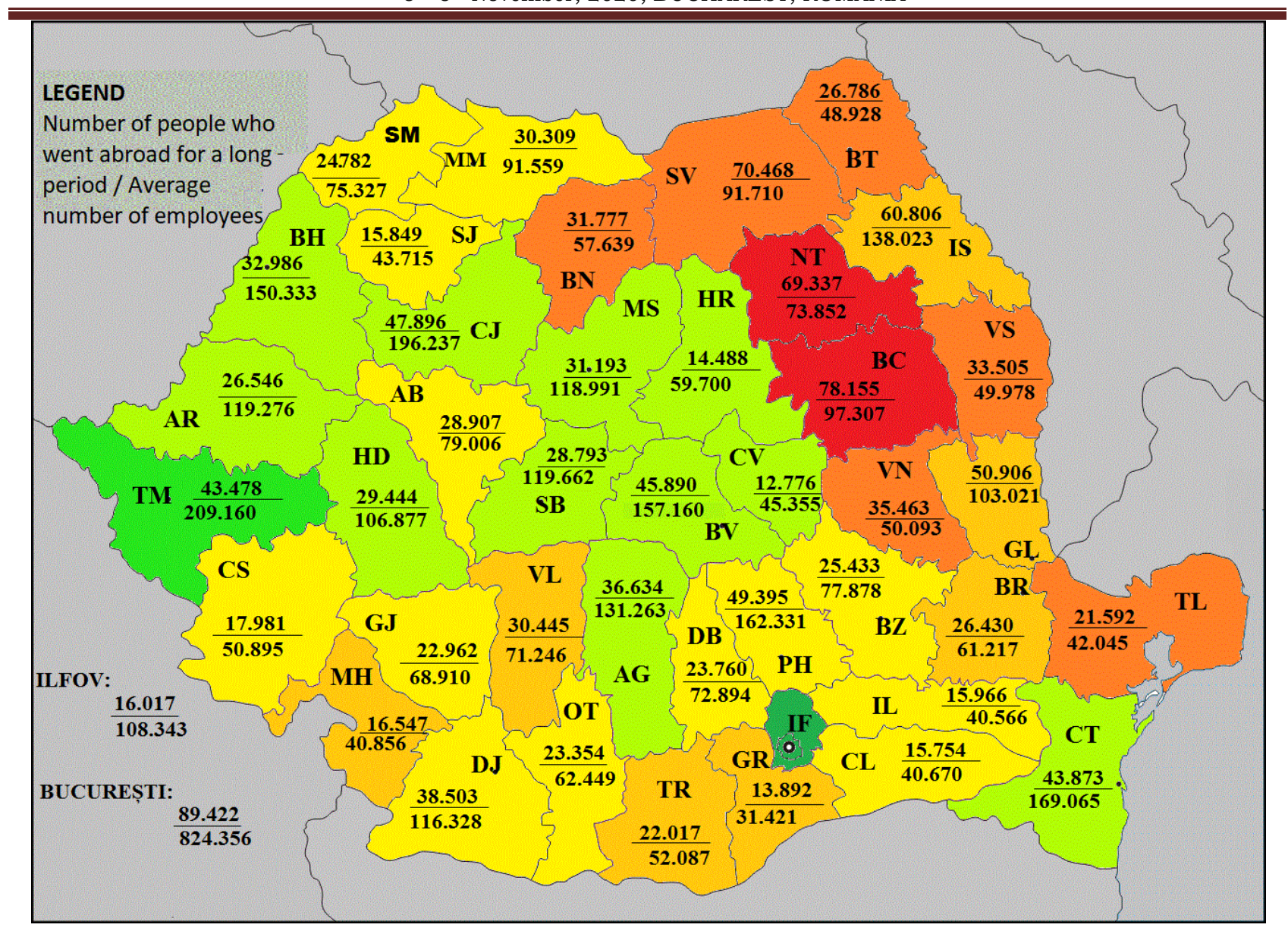

Figure 1. Emigration map: How many inhabitants Romania's counties have lost.

Source: $\underline{\text { https://cursdeguvernare.ro }}$

Since 1989, all these changes have taken place in Romania. Furthermore for strong migration, which matches natural growth and is thus mild, the years 2014 and 2017 are noted. As a result of a rapid and profound decrease in the birth rate and a re-launch of the death rate, natural demographic losses have been associated with negative external migration since 2015 (Bodislav et al., 2019).

\subsection{The case of Romania}

It is recognized that a range of factors have affected the demographic evolution of the last 10 years, including the right of couples to settle on the number of children they want and the time they need to have children, the high level of economic and social costs borne by the population during the transition period, the lack of accommodation and the poor access of young people to their own homes (Angheluta et al., 2019).

These considerations must be applied to external migration, which has contributed significantly to the decrease in the population of Romania (Burlacu et al., 2020): Romania has a global migration phenomenon, with a tradition of migration characterized by cycles of increase and decline, based primarily on domestic economic, social and political circumstances (Jianu et al., 2019).

Human life involves an endeavor to find better living conditions. The method of migration encompasses the subject matter (emigrant or immigrant), at least two countries (country of origin and country of destination, but also transitional countries), as well as the intent of acquiring a residence permit or of seeking jobs in the country of origin. Destination of Destination (Alpopi et al., 2018). There are two aspects of Romania's foreign migration: legitimate, objectively registered and migratory migration, and labor migration (Bodislav et al., 2020). The first section, varying from 
10 to 15 thousand migrants a year and several thousand immigrants a year is not very high. The high proportion of emigrants who study at a university level of close to 25 percent can be observed, with Germany, Italy, the USA and Canada being the main destination countries. Population flows consist of two components: reversible migration and a moderate number of Republic of Moldova refugees (Bran et al., 2018). For most Romanian refugees, this is the country of origin; some of them are interested in acquiring Romanian citizenship in order to seek opportunities for a better life in the European Union (Bran et al., 2018).

\section{LITERATURE REVIEW}

Literature is generous in its analysis of the relation between migration and economic growth from the point of view of migrant countries. A small number of scientific studies on this topic, however, exist. The outcomes of these experiments are often contradictory. For instance, Barro and Sala-iMartin (2017) show that in the United States and Japan, migration has a positive, albeit minor, effect on economic development. However the observational results of Blanchard and Katz (2017) are at odds with these results. They argue that geographic convergence is adversely correlated with migration (Jianu et al., 2019). The lack of evidence and contradictory findings mean that more study on this subject is needed, which encourages our approach (Angheluta et al., 2019). Numerous studies have measured the elasticity of substitution between immigrants and locals by calculating production functions (Costache et al., 2015).

Much of the latest studies contribute to the effect on the domestic labor market of the immigrant population by forecasting a reduced equilibrium between incomes and unemployment, in which the primary driving variable of concern is the proportion of immigrants from a region or industry (Androniceanu et al., 2017). Most scholars are based on vector instrumental figures to elucidate the challenge of isolating immigration as a source. There is no suggestion, from an economic point of view, of a major reduction in domestic employment (Burlacu et al., 2018). We have been driven to a related inference by the review of European literature (Bauer \& Zimmermann, 2016). No possible beneficial side effects on the goods markets, far less the indirect (positive effects of growing the variety of products and services) have been calculated to date (Dima et al., 2020).

In recent decades, the study of migration from the viewpoint of migrant countries has been less significant for scholars, but in recent years it has gained interest through the "brain drain" process, which it attenuates. In a population background, the mechanism is also approached. In Europe, populations are undergoing a somewhat disturbing aging trend that has led to the adoption of a payas-you-go social security system as a result of significant demographic pressure.

As Bonin's study indicates, public opinion is increasingly conscious that potential immigration regulations are designed to attract young, economically competitive immigrants and thereby reduce some of the generational pressure of the ageing process (2013). The OECD research Effects of migration on countries of origin: what do we know? indicates interest in researching the effects of migration on migratory countries. Elaborated by Katseli (2017).

Temporary migration appears to lead to a rise in remittances compared to permanent migration, especially where it involves low-skilled migrants waiting for their country of origin to return. Studies on the impact of migration in Romania suggest that economic development would be greatly affected if Western countries continued to attract labor from our country. They expect that Romania, a nation with labor market distortions, will prosper from migration in the short term, but will become a labor-importing country in the long run. 
$1990-1993$

ethnic

migration after 2007

free

1996-2001

beginning

movement
1994-1996

primary

migration

exploration

Figure 2. Stages of Romanian emigration after 1989

Source: own adaptation

Figure 2 reveals a variety of phases in the history of migration in Romania, but we are presented with the following situation after 1989:

- 2014-2015: permanent mass migration fleeing political turmoil and suffering of ethnic minorities

(German, Hungarian) and Romanians. Many requested political asylum in the West, exceeding 116,000 petitions in 2015;

- 2015-2016: low levels of Western European Romanian economic migration, mostly for seasonal or illegal jobs, but also very low levels of ethnic migrants and asylum seekers;

The emergence of many parallel patterns and the increase in migration transform the phenomenon into a dynamic one to be analyzed: -2016-2018:

a) permanent migration in the United States and Canada has increased, more than legal migration in European countries has occurred;

b) demonstrations, in particular since 1999, of irregular, 'incomplete' or circular migration for illegal work to European countries;

c) the increase in refugee trafficking, a phenomenon that overlaps with illegal migration but is characterized by traffickers'/employers' violence and harassment. This form of migration is considered to be especially prevalent among women.

d) the number of employment agreements with different European countries has declined since 1999 (Germany, Spain, Portugal, Italy);

e) a small number of returning Romanian migrants from the Republic of Moldova and a significant influx of returning Romanian migrants from Germany to Romania.

- 2014-2017: a rapid increase in circular migration was encouraged by the removal of the Schengen visa requirement, except to the extent that Romanians who had previously been 'blocked' in the Schengen countries were able to return to Romania to join the circular migration framework. The presence of the possibility of legal residency as a tourist for a period of three months has led to the development of a sophisticated circular migration method, focusing primarily on destinations like Italy and Spain (IOM, 2016). This new strategy made it possible to avoid regulating the European labor market, so that migrants ended up working illegally for a period of three months, sharing employment with other Romanians.

- 2017 - We have witnessed free access to the European labor market so far which, as can be seen, is beneficial both for the development of the European labor market and for the registration of significant slippages in local markets.

\subsection{Intensity and Consequences of Temporary Migration}

The most significant aspect of Romanian migration in recent years has been migration for jobs. Official statistics do not, unfortunately, cover the entire migration and employment phenomenon, with the relevant figures beginning to exist only in 2015. According to the Romanian Office for 
Labor Migration Statistics, there are approximately two million Romanians working out of seasonal practice abroad, accounting for more than $10 \%$ of Romania's population.

We are using data from the Living Temporary Abroad report in this article. Economic migration of Romanians: 1990-2018, carried out by the Open Society Foundation (FSD), which we consider to be nationally representative. Probabilistically, the sample of 1,400 people used for data collection at national level was planned in two phases of the model. In the first stage, the polling station was the selection unit, and the interviewees were in the second phase. More than a third of households had at least one migrant employed abroad during the time described in the above-mentioned study, according to the FSD.

In 2014, $62 \%$ of migrants in the $26-40$ age group, which is $58 \%$ of the immigrant population, were women, and the number is gradually increasing (Costache et al., 2015). As shown by the fact that a growing number of children are born abroad, the adverse effects on birth rate and fertility are becoming more and more prominent (Burlacu et al., 2019). There are numerous consequences of the migration phenomenon at the family level, both in terms of positive and negative effects (Bodislav et al., 2020). The money that migrants send to their families helps improve the quality of their lives, with positive implications for family ties (Jianu et al., 2019).

On the other hand, due to the absence of one or more members, we face the family's pain, even temporarily. In reality, the longer the duration, the stronger the impact on the family. One member's departure affects the reorganization of roles within the family (Rădulescu et al., 2018). In this situation, the roles/functions of the relevant migrant are taken over by family members, which can lead to a loss of well-being within the family and to imbalances in the relationship between the couple. All of this can lead to a family break-up quickly (divorces). In relation to the children of migrants living with only one of their parents, one of the most significant negative consequences of labor migration tends to be (in the happiest case).

There are also situations where both parents move to work and then the kids are taken care of by grandparents, other relatives or friends. Migrants frequently abandon their children, who ultimately end up in state care. As a result, children are affected to a very significant extent by their parents (in some situations these conditions become traumatic), because the individuals they care about may not play the role of parent adequately (Bran et al., 2018).

Older people are another social group which, particularly in communities with a high level of migration, may be adversely affected. If kids leave the country with their parents, they have to go through an adjustment period, learn a foreign language and learn to survive in a different social setting, which often entails a certain degree of tension (Negescu Oancea, et al., 2019).

According to the study described above in the period 1990-2018, most people in households with members who have gone abroad do not feel any shift in family relationships. Starting with the FSD report, we developed our own research model (Angheluta et al., 2019).

Most people in households with members who have gone abroad do not experience any difference in family relationships, according to the study mentioned above for the period 1990-2018. We developed our own research model, beginning with the FSD study (Angheluta et al., 2019).

We considered the fact that someone has been overseas in your home for a while and the degree to which this had consequences on children to be a predictor for you. As a result, we found that in this respect, just 11 per cent of respondents said they had problems with their daughters.

Although the number of respondents who state they are impaired is tiny, there are gaps between the different categories of respondents. Therefore we will find that individuals with work experience abroad respond in a greater proportion than others that their experience has led to any improvements in family relationships. 


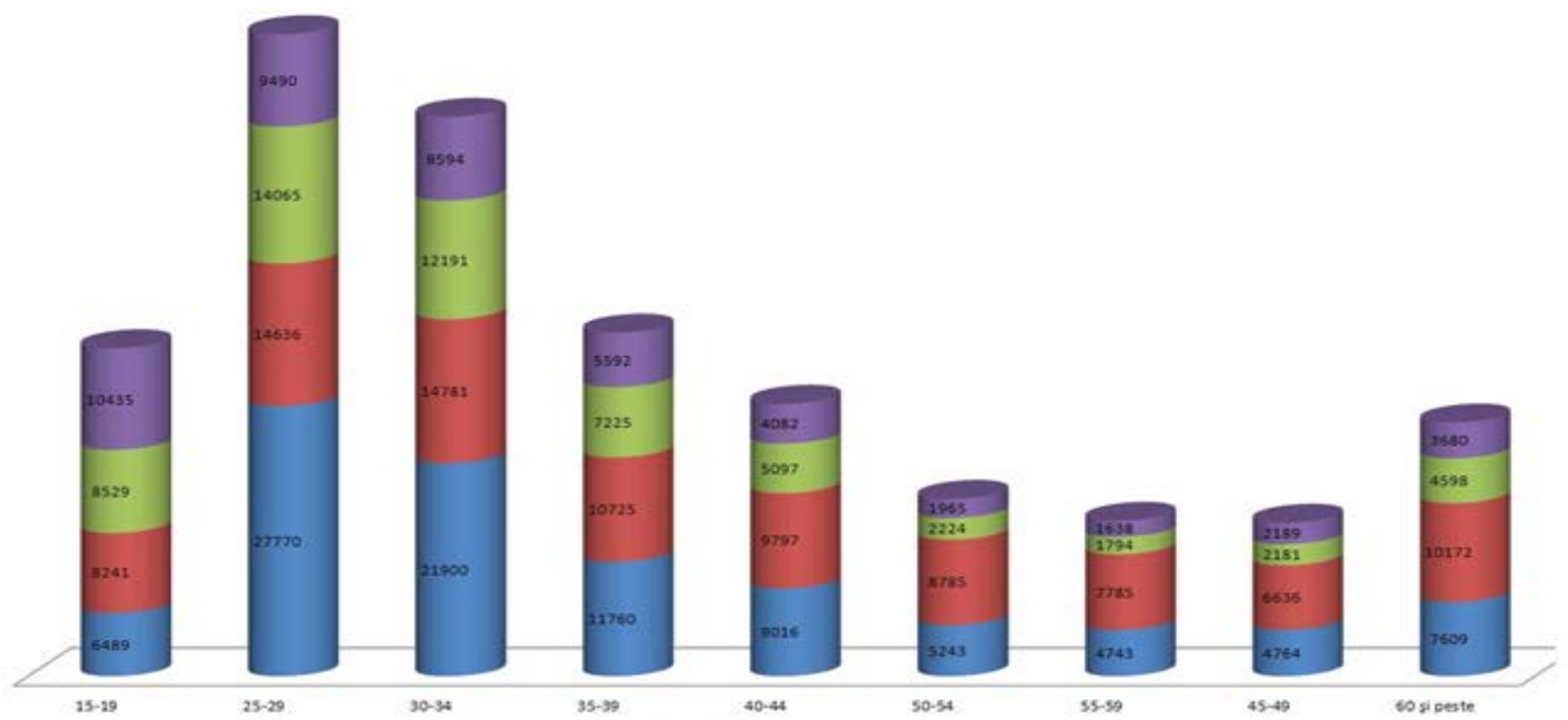

Figure 3. Internal migration of the population by age groups

Source: INS

Migrants tend to conclude that their time abroad has a positive influence on family relationships, taking into account that the income they gain from working abroad leads to the enhancement of the quality of life of immigrant households and hence the improvement of family bonds. The influence on the lives of their children is not recognised by them, thereby neglecting their future development.

\subsection{Impact on temporary economic migration}

It is essential to present the economic impact of labor migration from the viewpoint of this article. There is a general opinion that transient migration, as a result of the experience obtained by living overseas, would help improve the skills of a migrant (Androniceanu et al., 2017). The aim is to test the following hypothesis in this context: if the experience of migration abroad has an effect on the income earned after returning to the country of origin (Alpopi et al., 2018).

Income was then called the dependent variable and the following series of independent variables: education valued by the last graduate of school; machine use knowledge; job experience and work experience abroad (Profiroiu et al., 2019). We applied multiple linear regression to a sample of 1,032 individuals with or without work experience abroad, using data from the FSD analysis.

The results of a multiple linear regression in which income was added as a normal logarithm are shown in Table 1 . The results of a multiple linear regression in which income was added as a normal logarithm are shown in Table 1 . For $\mathrm{p}=0,05$, all coefficients (marked as bold) are important.

Table 1. Results of multiple linear regression on income

\begin{tabular}{|l|r|r|r|r|c|}
\hline \multicolumn{1}{|c|}{ Factors } & \multicolumn{2}{c|}{$\begin{array}{c}\text { Non-standardized } \\
\text { coefficients }\end{array}$} & $\begin{array}{l}\text { Standardized } \\
\text { coefficients }\end{array}$ & t & Sig. \\
\hline & $B$ & Std. error & Beta & & \\
\hline Constant & 0,924 & 0,198 & & 4,658 & 0,000 \\
\hline Education (last level of study completed) & 0,194 & 0,012 & 0,747 & 15,946 & 0,000 \\
\hline IT\&C skills & 0,410 & 0,067 & 0,206 & 6,142 & 0,000 \\
\hline Work experience & 0,169 & 0.024 & 0,208 & 7,023 & 0,000 \\
\hline Work abroad & 0,221 & 0,073 & 0,078 & 3,024 & 0.003 \\
\hline
\end{tabular}

Source: own calculations 
The ANOVA analysis indicates that the model is statistically relevant and that 0.336 is the approval ratio. The four properly regarded factors also characterize the fluctuations of population wages, in proportion to 33.6 per cent, as a result of the experience obtained by migrants.

The following results from the regression model were drawn after the experiment on the impact of the experience acquired by working abroad on the income earned by migrants on their return to their country of origin:

1. Positive effects of temporary jobs abroad on the wages of migrants returning to their country of origin (positive correlation);

2. The most significant factor affecting income levels is schooling, as predicted. The greater the individual's educational level, the higher the salary (positive correlation);

3. Job knowledge and computer-related abilities (positive correlation) directly impact income;

4. We also evaluated the effect of language knowledge on income in the current model, but this factor did not have a significant influence, which is why it was excluded from the model's initial form.

It is possible to quantify the direct impact of international migration by analyzing contributions made from capital earned abroad. The investment research also allows one to observe the degree to which these sums are spent by households or, on the other hand, only spend them on purchasing consumer goods (Rădulescu et al., 2018).

Global figures reveal that a significant proportion of the Romanian population has bought durable goods over the last five years: 50 percent of Romanians buy household goods, 37 percent opt for home extension/modernization, and 16 percent buy cars, etc.

In this case, irrespective of the products bought, nearly $10 \%$ of the spent amounts are retrieved from migration operations. We will see that more than 50 percent of them spend in order to expand/modernize their homes and that a similar sum is allocated to the purchase of household goods if we restrict the analysis to the level of individuals who buy goods because of money from international migration.

In the last five years, a substantial proportion (about 21 percent) of households have spent money on owning one or more vehicles.

Two closely linked components of life are work migration and entrepreneurship. When a person wants to develop a business, work experience acquired abroad, along with entrepreneurship, is linked. When a migrant accumulates physical, human and relational capital and achieves his basic needs, he proceeds to spend, being an entrepreneur, in profitable activities.

Cross-border practice is an intermediary approach for an entrepreneurial strategy for a large portion of Romanian migrants, related to a strong association between experience obtained abroad and entrepreneurial orientation, both behavioural and intentional.

The above findings give rise to a number of outward migration economic impacts. The most critical implications are the serious slippage and the multitude of labor market dysfunctions, among which we mention:

- job potential;

- the unemployment rate and features thereof;

- the mass transfer of professional labor-the lack of "brain" capable of creating higher added value;

- salary gaps and labor segmentation;

- the amplification of the underground economy (work 'unreported');

- decreasing local labor force capacity;

- the use of foreigners to make up for urban labour force deficits.

There are a number of positive geographical effects in addition to these aspects of migration. The decline in unemployment in most large migratory countries, such as Romania, as well as Poland, Slovakia and Bulgaria, is the most notable short-term consequence. 
In fact, if migration includes unemployed workers, the budgetary impact is also optimistic (because fewer people will apply for unemployment benefits).

The positive socio-political influence should not be underestimated either, considering that high levels of unemployment are frequently associated with social inequalities that involve significant budgetary spending to restore social order (especially in areas with a very high unemployment rate). Another positive impact is that we think it is important to reduce the pressure on the Romanian government's reforms. Labor displacement abroad has relaxed urban labor markets as well as the pressure of social support in some areas/regions.

In other areas/regions, migration to better employment has resulted in labor shortages which have an effect on local and social economic growth prospects. Indeed, Romania's provinces, which have strong migrant flows, have the largest labor shortages.

Foreign exchange is another advantageous effect of migration, with strong effects on both microeconomics and macro-economics. According to the National Bank of Romania, these transactions amounted to US\$ 1,753.5 billion in 2014 and US\$ 4,440.9 million in 2015, or 4.51\% of Romania's GDP in 2015.

Owing to multiple interactions at the level of macroeconomic factors, the consequences of money flows at the macroeconomic level are difficult to calculate. This transfers have visible investment and savings effects. The aggregate domestic demand component of GDP is the most visible effect of these transfers on household spending, which is so important at the macro-economic stage.

Money transfers to households are direct sources of revenue growth, leading to higher demand and thus to a transient reduction in poverty. In their redistributive effect, these quantities have the ability to minimize social polarization.

Western nations will encourage immigration and the labour force will be represented by Eastern European countries, including Romania, in order to avoid the problem of natural population loss in the coming years. There are huge economic consequences for these migrant trends. In this paper, we examined the demographic effects particularly because the community that has emigrated in recent years for economic reasons is characterized by the young population (aged 30).

With regard to the financial dimensions and the quality of life of Romanians, significant economic consequences have been found, as the total of the amounts transferred amounted to approximately EUR 7 billion in 2017. We are also met with a particular social impact on migrants' family lives. The most serious concern is the temporary abandonment of children by migrant parents in search of a better job and the determination of the authorities to develop steps to monitor the situation, which will require extra costs.

\section{CONCLUSIONS}

The consequences of migration are both temporary and permanent, from a demographic point of view. In the destination countries, the tendency to remain permanently is well known and results in major losses among the population. A reduction in the rate of economic growth or even a decrease in economic activity is the result of this loss. Recent studies have shown that international mobility among working-age individuals is greater. As a result, migrant countries are facing an increased aging process for their own populations. The human factor is the most significant source of economic growth, and if they live in their home world, growth rates are projected to be lower. Most emigrants are young and their proportion is constantly increasing, hence being able to claim that migration affects high fertility age classes, thus reducing the potential of newborns in Romania. When displacement becomes permanent, this is all the more worrying. In the background of gender migration, there are many changes, so that immigrant women have been more and more numerous in recent years. Owing to multiple interactions at the level of macroeconomic factors, the consequences of money flows at the macroeconomic level are difficult to calculate. This transfers have visible investment and savings effects. 
In Romania, the evolution of external migration is not well known. On economic grounds, Western countries now need foreign labour. Few Western nations are beginning to witness a slight natural demographic loss, and this natural decline is being compensated for by globalization, so that the population does not change significantly. Romania's global migration will be influenced over the next decade by the quick and sustained rate of economic development, to the point that this growth will significantly raise the quality of living and of course, Western countries' immigration policies. The first signs of recovery in Romania are according to existing scenarios, somewhat unpredictable as a result of the severe destabilisation triggered by the economic crisis. This essay concludes by assuming that first and foremost, global evolution is impacting the migration process, opening up new possibilities for future study.

\section{REFERENCES}

Alpopi, C., Burlacu, S., Ioviţu, M. (2018). Procesul de globalizare şi politicile ecologice. In Competitivitatea şi Inovarea în Economia Cunoaşterii (pp. 317-324 ), Vol. 2. Chișinău, Republica Moldova: Departamentul Editorial-Poligrafic al ASEM

Androniceanu, A., Burlacu, S., Drăgulănescu, I. V. \& Nicolae, E. E. (2017). New trends of businesses digitalization in Romania and the behaviour young consumers. BASIQ International Conference: New Trends in Sustainable Business and Consumption 31, 27-35

Angheluta, S. P., Burlacu, S., Diaconu, A., \& Curea, C. S. (2019). The Energy from Renewable Sources in the European Union: Achieving the Goals. European Journal of Sustainable Development, 8(5), 57.

Barro, R.J., Sala-i-Martin, X. (2015). Economic Growth, New York: MacGraw-Hill

Bauer, T., Zimmermann, K.F. (2016). Causes of international migration: a survey. In C. Gorter, P. Nijkamp, J. Poot (Eds.), Crossing Borders: Regional and Urban Perspectives on International Migration (pp. 95-127), Aldershot: Ashgate

Blanchard, O., Katz, L. (2015). Regional evolutions. Brookings Papers on Economic Activity, 1, $1-61$

Bodislav, A. D., Rădulescu, C. V., Moise, D., \& Burlacu, S. (2019). Environmental Policy in the Romanian Public Sector. Bucharest: ASE Publishing House.

Bodislav, D. A., Buzoianu, O. A. C., Burlacu, S., \& Rădulescu, C. V. (2020). Analysis of companies in Romania from the perspective of risk perception and the management needs thereof. Economic Convergence in European Union, 341.

Bran, F., Burlacu, S., \& Alpopi, C. (2018). Urban Transport of Passengers in Large Urban Agglomerations and Sustainable Development. Experience of Bucharest Municipality in Romania. European Journal of Sustainable Development, 7(3), 265-273.

Bran, F., Rădulescu, C. V., Bodislav, D. A., \& Burlacu, S. (2020). Environmental risks in the context of globalization. Economic Convergence in European Union, 350.

Bran, F., Alpopi, C., \& Burlacu, S. (2018). Territorial Development-Disparities between the Developed and the least Developed Areas of Romania. LUMEN Proceedings, 6(1), 146-155.

Burlacu, S., Alpopi, C., Mitrită, M., \& Popescu, M. L. (2019). Sustainable e-Governance and Human Resource Development. European Journal of Sustainable Development, 8(5), 16.

Burlacu, S., Gavrilă, A., Popescu, I. M., Gombos, S. P., \& Vasilache, P. C. (2020). Theories and Models of Functional Zoning in Urban Space. Revista de Management Comparat International, 21(1), 44-53.

Burlacu, S., Profiroiu, A., \& Vasilache, P. C. (2019). Impact of Demography on the Public Finance of the European Union. Calitatea, 20(S2), 136-138.

Burlacu, S.; Alpopi, C.; Popescu, M. L. (2018) Omul și degradarea mediului natural. Efecte distructive. In Competitivitatea şi Inovarea în Economia Cunoaşterii (pp. 159-165) Vol.1. Chisinau, Republica Moldova: Departamentul Editorial-Poligrafic al ASEM. 
Costache, G., Marinas, C. V., Igret, R., \& Burlacu, S. (2015). Internship in the HR DepartmentOrganizational and Individual perspectives. Paper presented at the International Management Conference. Bucharest, Romania

Dima, C., Burlacu, S., \& Buzoianu, O. A. C. (2020). Strategic Options for the Development of Ecotourism in the Danube Delta in the Context of Globalization. Paper presented at The $19^{\text {th }}$ International Scientific Conference Globalization and its Socio-Economic Consequences 2019 - Sustainability in the Global-Knowledge Economy.Rajecke Teplice, Slovakia

Goschin, Z., Constantin, D., Roman, M. (2015). The partnership between the state and the church against trafficking in persons, Journal for the Study of Religion and Ideologies, 24(8), 231256

IOM (2016). World Migration 2016 - Maps, Geneva: Organizaţia Internaţinală pentru Migraţie Dictionar de Economie, Catedra de Economie şi Politici Economice, Economica, Bucharest

Jianu, I., Dobre, I., Bodislav, D. A., Radulescu, C. V., \& Burlacu, S. (2019). The Implications of Institutional Specificities on the Income Inequalities Drivers in European Union. Economic Computation and Economic Cybernetics Studies and Research, 53(2), 59-76.

Katseli, L.T., Lucas, R.E.B., Xenogiani, T. (2016). Effects of Migration on Sending Countries: What Do We Know?, OECD Development Centre, Working Paper No. 250. doi: https://doi.org/10.1787/18151949

Negescu Oancea, M. D., Burlacu, S., Buzoianu, O. A. C., Mitrita, M., \& Diaconu, A. (2019). Strategic Options for the Development of Ecoturism in the Dornelor County. The USV Annals of Economics and Public Administration, 19(1 (29)), 21-28

Profiroiu, A., Burlacu, S., \& Sabie, O. (2019). Reform of the Pension System in Romania. Calitatea, 20(S2), 521-524

Rădulescu, C. V., Bodislav, D. A., \& Burlacu, S. (2018). Demographic Explosion and IT Governance in Public Institutions. Managerial Challenges of the Contemporary Society, 11(1), 18

Rădulescu, C. V., Dobrea, R. C., \& Burlacu, S. (2018) The Business Management of Distress Situations. Paper presented at The 12th International Management Conference 